\title{
PERFORMANCE OF LAYERS FED TOASTED, BOILED OR BOILED AND SOAKED CASTOR OIL SEED MEAL ( $R$. COMMUNIS)
}

\author{
RESPUESTA PRODUCTIVA DE PONEDORAS ALIMENTADAS CON HARINA DE SEMILLA \\ DE RICINO (R. COMMUNIS), TOSTADA, COCIDA Y COCIDA Y HÚMEDA
}

Nsa, E.E. ${ }^{1}$, Ukachukwu, S.N. ${ }^{2}$, Isika, M.A. ${ }^{1}$ and Ozung, P.O. ${ }^{1 *}$

${ }^{1}$ Department of Animal Science. University of Calabar. Calabar. Nigeria. *ozungpascal@unical.edu.ng ${ }^{2}$ Department of Animal Nutrition and Forage Science. Michael Okpara University of Agriculture. Umudike. Nigeria.

\section{Additional KeYWORDS}

Egg quality. Layers. Processing. Ricin.

\section{SUMMARY}

A feeding trial was conducted to investigate the response of Isa Brown laying hens to three different methods of processing castor oil seed meals (CSM); toasting, boiling and boiling-andsoaking for using as total substitute for soybean meal. Two hundred, 75-week old laying birds were randomly assigned to four experimental diets in a completely randomized design experiment. The control diet (CD) contained $19.10 \%$ soybean; the proportion of soybean in the CD $\left(T_{1}\right)$ was replaced completely with toasted, boiled and boiledand-soaked castor oil seed meal in diets $T_{2}, T_{3}$ and $T_{4}$ respectively. Chemical analysis showed that treatment methods did not have any significant ( $p>0.05$ ) effect on the dry matter (DM), crude fibre (CF), ether extract (EE), ash, nitrogen free extract (NFE) and gross energy of the meal. However, the crude protein value of the toasted meal $(24.55 \%)$ decreased $(p<0.05)$ significantly as compared to the other two treatment methods. Toasted method also retain significantly $(p<0.05)$ higher level of ricin value $(0.21 \mathrm{mg} / 100 \mathrm{~g})$ when compared to boiling $(0.09 \mathrm{mg} / 100 \mathrm{~g})$ and boiling-and-soaking $(0.03 \mathrm{mg} / 100 \mathrm{~g})$. Birds on the control diet, $T_{3}$ and $T_{4}$ had numerically $(p>0.05)$ similar values of final live weight, weight gain, feed conversion ratio and hen day production that were significantly $(p<0.05)$ favorable than birds on $T_{2}$. Birds on $T_{2}$ also had significantly $(p<0.05)$ depressed liver weight $(2.11$ $\%)$ as compared to birds on the control diet (2.87 $\%)$. Haemoglobin $(\mathrm{Hb})$ values also showed a significant decrease $(p<0.05)$ in birds on $T_{2}(2.23$

\section{Palabras clave adicionales}

Calidad de huevo. Ponedoras. Procesamiento. Ricino.

$\mathrm{g} / \mathrm{dL})$ than that of birds on the control $(10.67 \mathrm{~g} / \mathrm{dL})$, $T_{3}(10.11 \mathrm{~g} / \mathrm{dL})$ and $T_{4}(10.35 \mathrm{~g} / \mathrm{dL})$. Birds on $T_{2}$ equally had a significantly $(p<0.05)$ decreased RBC $\left(154.33 \times 10^{3}\right)$ in relation to the control diet $\left(288.02 \times 10^{3}\right)$. The egg quality parameters were not significantly $(p>0.05)$ affected by the test ingredient apart from promoting lighter egg yolk coloration. The study showed that boiled and boiled-and-soaked CSM can totally replace soybean meal in layers diet without any adverse effect on egg production, external and internal egg qualities, except encouragement of lighter yolk coloration. Boiling-and-soaking however, as a processing method had no special advantage in terms of egg production parameters and egg quality parameters, hence the additional task of soaking after boiling was unnecessary. Boiling of castor oil seed for 40 minutes is therefore preferred among the treatment methods. As an industrial waste, CSM incorporation in layer diets as a feed ingredient especially for large scale operations would results in substantial cost savings.

\section{RESUMEN}

Un ensayo de alimentación fue realizado para investigar la respuesta de gallinas ponedoras Isa Brown a tres métodos diferentes de procesamiento de las semillas de ricino (CSM); que son tostado, hervido y hervido humedecido para usarlos como sustitutos totales de la harina de soja. Doscientas gallinas ponedoras de 75 semanas 
fueron aleatoriamente asignadas a 4 dietas experimentales en un diseño completamente al azar. La dieta control (CD) contenía 19,1 \% de soja; la proporción de soja en la CD (T1) fue sustituida completamente con harina de semilla de ricino, tostada, hervida y hervida y humedecida en las dietas T2, T3 y T4 respectivamente. Los análisis químicos demostraton que los métodos aplicados no tuvieron efectos significativos sobre la materia seca, fibra bruta, extracto etéreo, cenizas, extracto no nitrogenado y energía bruta de la harina. Sin embargo, la proteina bruta de la harina tostada $(24,55 \%)$ disminuyó $(p<0,05)$ en comparación con los otros 2 tratamientos. El método de tostado mantuvo significativamente $(p<0,05)$ elevados valores de ricina $(0,21 \mathrm{mg} / 100 \mathrm{~g})$ comparado al hervido $(0,09 \mathrm{mg} / 100 \mathrm{~g})$ y el procedimiento de hervido y humidificación $(0,03 \mathrm{mg} / 100 \mathrm{~g})$. Las aves de las dietas control, T3 y T4 determinaron valores numericamente similares del peso vivo final, ganancia de peso, conversión alimenticia y producción diaria por gallina que fueron significativamente $(p<0,05)$ favorables respecto a las aves del T2. Las aves del T2 tuvieron también un peso del hígado $(2,11 \%)$ menor $(p<0,05)$ que las de la dieta control (2,87\%). La hemoglobina también demostró un descenso significativo en las aves del T2 $(2,23 \mathrm{~g} / \mathrm{dL})$ respecto a las de la dieta control $(10,67 \mathrm{~g} / \mathrm{dL}), \mathrm{T}_{3}(10,11 \mathrm{~g} / \mathrm{dL})$ y $\mathrm{T}_{4}(10,35 \mathrm{~g} /$ $\mathrm{dL})$. Igualmente las aves del T2 tuvieron valores inferiores de $\mathrm{RBC}\left(154,33 \times 10^{3}\right)$ en relación con la dieta control $\left(288,02 \times 10^{3}\right)$. Los parámetros de calidad del huevo no fueron afectados por los ingredientes probados aparte de la coloración de la yema. El estudio demostró que la CSM hervida o hervida y humedecida puede reemplazar totalmente a la harina de soja en la dieta de ponedoras sin ningún efecto adverso sobre la producción de huevos, calidad interna y externa, salvo una coloración más clara de la yema. El hervido y humedecido sin embargo, no ttiene especial ventaja como método de tratamiento en términos de producción y calidad de huevos, por lo que la tarea adicional de humedecer después del hervido es innecesaria. El hervido de la semilla de ricino durante 40 minutos, es por ello, preferible a los otros métodos. Como residuo industrial la incorporación de CSM en la dieta de ponedoras como ingrediente alimenticio, especialmente en operaciones a gran escala puede dar lugar a considerables ahorros de costes.

\section{INTRODUCTION}

In Nigeria, one of the major problems facing the livestock industry is that of increasing unavailability of the conventional feedstuffs. The competition between humans and monogastrics for these grains has further hiked prices, thereby threatening the potential for increasing animal protein production, which is in short supply (Bawa et al., 2007). This has led to the search for alternative feedstuffs for animal production. Such alternatives according to Oyebiyi et al. (2007) should of necessity be available all year round; easy to be procured and processed, if need be, into usable forms and must have a comparable cost advantage over the conventional feedstuffs.

One of such important but lesser known plant protein sources is the castor oil seed (Ricinus communis). The seeds are obtained from the castor tree, an evergreen herbaceous or semi woody long shrub or small tree that gets up to $40 \mathrm{ft}(12 \mathrm{~m})$ tall and $15 \mathrm{ft}(4.6 \mathrm{~m})$ in diameter (Weedfact, 2003), widely distributed in Tropical Africa, in India and Temperate regions (FAO, 1997). In Nigeria, castor oil bean is distributed in a number of the Southern States including Nsukka, Awka, Anambra, Bendel, Imo and Cross River States (Okorie et al., 1985 and Rehman, 1999). The raw seed is high in protein 32.80 to $40.00 \%$ (Okorie et al., 1985; Nsa and Ukachukwu, 2009), with an ideal amino acid profile that is moderately high in cystine, methionione, tryptophan and isoleucine (Harnold, 2002).

The seeds, leaves and stems of castor plant are poisonous to people, animals and insects due to the toxic protein known as ricin, a phytotoxin believed to have cytostatic and cytotoxic effects in the cells and exhibits antitrypsin action as in some legumes (Clarke and Clarke, 1975). Castor oil bean also has agglutinating property. The agglutination is believed to be due to RCA (Ricinus communis agglutinin). However, poisoning caused by ingestion is only due 
to ricin, as RCA does not affect red blood cells unless given intravenously (Vietta and Thorpe, 1991).

Autoclaving, cooking or boiling, steam heating, infra-ray cooking, extrusion cooking, toasting, salt-bed roasting and radio frequency dielectric heating methods have been employed in detoxifying castor oil seeds (Raghavan et al., 1974; Borchers etal., 1972; Gustafson et al., 1971; Waldroup and Hazen, 1978; Udedibie et al., 1996; IFSP, 1988). Some of these treatments are locally adaptable by farmers and feed millers in Nigeria since they do not involve sophisticated equipment or huge capital investment (Ukachukwu and Obioha, 1997). These include cooking, soaking and boiling.

The possibility of using castor oil bean meal as a feeding stuff has shown no adverse effect or pathological changes in rats, guinea pigs, sheep, cows and birds fed up to $20 \%$ detoxified castor oil bean meal (Nsa et al., 2010).

Though thermal treatments is a very successful method of detoxifying or inactivating ricin, researches showed that steaming of castor seeds for 15 minutes was unsuccessful as witnessed by the $95 \%$ mortality among the fed chicks. Chicks fed diets with $40 \%$ autoclaved castor pomace left some residue of toxic substance, but when washed with water, $\mathrm{HCl}$ or Ethanol, satisfactory result was obtained (Okomato et al., 1965). Autoclaving of allergen isolated from ricin for one hour eliminated the toxin completely, implying that, direct boiling destroys and eliminates ricin in castor seeds (Poliankoff, 1980). Okorie et al. (1985) showed that ricin components can be destroyed by roasting the bean at $140^{\circ} \mathrm{C}$ for 20 minutes.

The nutritive composition and digestibility of a dehulled castor seed are said to improve when heated longer in steam (Clemens and Vern, 1965). However, excessive thermal treatment reduces the nutrient content of the seed either through denaturation or solubilisation and subsequent leaching (Ukachukwu and Obioha, 1997, Nsa and Ukachukwu, 2009). Earlier report showed that amino acid value of toasted seed could worsen with excessive heat treatment while autoclaving was shown to destroy cystein (D'Mello et al., 1985).

Unlike broiler and rabbit production, there is little information on complete replacement of soybean meal with castor oil seed meal in layer feeds. The present study is therefore designed to investigate the extent to which locally adaptable thermal processing methods can improve the nutritive value of castor oil bean in egg production, egg quality parameters, haematological and serum chemistry of laying birds.

\section{MATERIALS AND METHODS}

The study was conducted at the Poultry Unit of the Department of Animal Science Research and Teaching Farm, University of Calabar, Nigeria. Castor oil bean seeds and other feed ingredients used for the study were bought from Ogoja local Markets in Cross River State of South-South Nigeria.

\section{Processing of CASTOR OIL BEAN SEEDS}

The large mottled variety of castor bean seeds were used for this study. The undecorticated seeds were divided into three portions. One lot was subjected to boiling for 40 minutes as described by Ani and Okorie (2006), the other by 30 minutes boiling followed by soaking for 48 hours, while the last lot was toasted for 30 minutes as described by Nsa and Ukachukwu (2009).

Boiled seeds (40 minutes). Water was brought to boiling at $100{ }^{\circ} \mathrm{C}$ before the castor seeds were poured in. Boiling continued at $100-105^{\circ} \mathrm{C}$ for 40 minutes. At the end of boiling water was drained off. The seeds were then thinly spread out on a concrete floor and sun dried for 5 days. The dry seeds were ground in hammer mill, defatted and stored in air tight bag.

Boiled (30 minutes) and soaked (48 
hours) seeds. Seeds were poured into boiling water and allowed to boil for 30 minutes. Water was then drained off, followed by soaking in water that was 5 times the volume of the seeds for 48 hours. Decanting and drying followed the same procedure.

Toasted seeds (30 minutes). Sand was poured into a drum and made to attain a temperature of $140^{\circ} \mathrm{C}$ using firewood before introducing the seeds. Turning was carried out frequently. At the end of 30 minutes, sand was immediately sifted out by means of a sieve and the seeds spread out to cool.

Analysis. Equal samples in each batch of the processed castor seed meals (CSM) were collected, ground and bottled in airtight containers for chemical analyses (Nsa et al., 2010).

Determination of proximate composition of the sample was by AOAC (1995) procedure, employing the micro-Kjeldahl method for crude protein (CP) and Soxhlet extraction method for ether extract (EE). Nitrogen free extract was determined by difference. The gross energy of the samples was assayed using the adiabatic oxygen bomb calorimetric technique.

Ricin was extracted and isolated by method similar to that of Mise et al. (1971). The potent ricin component was extracted from the ground castor seed meal with methanol under reflux for 24 hours.

\section{EXPERIMENTAL BIRDS: MANAGEMENT AND DIET}

Two hundred (200), 75 week old Isa Brown strain laying birds from a commercial farm in Cross River State were used for the study. The birds were weighed and randomly allotted to the four treatment groups of 50 birds each with five replicates of 10 birds each. They were managed intensively in a two-tiered battery caged unit. Two birds were housed in each compartment of the cage measuring 30x38x48 cm. Coccidial and bacterial treatments that served as part of the birds routine management continued within the period with the administration of wormazine. The experiment lasted for 10 weeks, with 2 weeks serving as a stabilization period.

Four experimental diets were formulated (table I) in such a way that soybean meal was replaced by each of toasted, boiled, boiled-and-soaked CSM denoted as $\mathrm{T}_{2}, \mathrm{~T}_{3}$ and $\mathrm{T}_{4}$ respectively, while $\mathrm{T}_{1}$ was the control. The crude protein (\%) and metabolisable energy $(\mathrm{kcal} / \mathrm{kg})$ contents of the feed were within the recommended range (NRC, 1994). Feed and water were given to the birds ad libitum.

\section{EXPERIMENTAL DESIGN AND DATA CO- LLECTION}

The experiment was designed to be a completely randomized design and lasted for 10 weeks. Individual birds were weighed at the commencement of the experiment, and subsequently weighed weekly. Feed consumption was measured by calculating the difference in the quantity of feed offered daily and the quantity left. Egg weight was recorded daily while the mean hen day production (HDP) was computed weekly from the production records. The HDP was calculated as number of eggs produced/ number of hens x number of days x 100. Birds were closely observed for mortality to effect adjustment in feed calculation.

Egg quality characteristics were determined from two freshly laid eggs, free of cracks, from each replicate using the following parameters; egg weight, yolk weight, albumin weight, shell weight, albumin height, shell thickness, yolk thickness, yolk height, yolk width, yolk index, haugh unit and yolk colour.

Egg weight and albumin height were used to compute the haugh unit using the simple formula of Haugh (1937).

Albumin height $(\mathrm{mm})$ was taken as the height of the thick white of the chalazae at a point about the midway between the inner and outer circumference of thick white with tripod micrometer (P6085 spherometer) having an accuracy of $0.01 \mathrm{~mm}$. 
Yolk weight (g) was obtained by separating the yolk from the albumen using a plastic egg separator and thereafter weighed with the use of electronic sensitive weighing balance. The yolk width $(\mathrm{cm})$ was measured around the widest horizontal circumference using vernier caliper. Yolk colour was graded with the Hoffman-laRoche, with yolk colour intensity from pale yellow (Score 1) to deep orange (Score 15).
Blood samples from 2 birds per replicate at the $10^{\text {th }}$ week of the experiment were collected through the wing vein into ethylene diamine tetra-acetate (EDTA) bottles for haematological studies; packed cell volume (PCV), haemoglobin concentration $(\mathrm{Hb})$ and red blood cell counts $(\mathrm{RBC})$ were determined using Wintrobes microhaematocrit, colorimetry cyanomethaemoglobin method and improved neubauer

Table I. Composition of layer diets containing toasted, boiled and boiled-and-soaked processing methods of castor oil seed meal (CSM). (Composición de las dietas de las ponedoras a base de semilla de ricino (CSM) tostada, hervida, y hervida y humedecida).

\begin{tabular}{lcccc}
\hline & Control diet & Toasted & Boiled & Boiled- soaked \\
\hline Ingredients (\%) & & & & \\
Maize & 52.00 & 52.00 & 52.00 & 52.00 \\
Wheat offal & 16.50 & 16.50 & 16.50 & 16.50 \\
CSM & 0 & 19.10 & 19.10 & 19.10 \\
Soy bean meal & 19.10 & 0 & 0 & 0 \\
Fish meal & 2.0 & 2.0 & 2.0 & 2.0 \\
Bone meal & 3.00 & 3.00 & 3.00 & 3.00 \\
Oyster shell & 6.50 & 6.50 & 6.50 & 6.50 \\
Salt & 0.35 & 0.35 & 0.35 & 0.35 \\
Methionine & 0.15 & 0.15 & 0.15 & 0.15 \\
Lysine & 0.15 & 0.15 & 0.15 & 0.15 \\
Vit./min. Premix & 0.25 & 0.25 & 0.25 & 0.25 \\
Total & 100 & 100 & 100 & 100 \\
Calculated analysis (\%) & & & & \\
Crude protein & 16.25 & 15.18 & 15.90 & 15.45 \\
Ether extract & 2.83 & 2.90 & 2.96 & 3.13 \\
ME(kcal/kg) & 2558.05 & 2571.43 & 2593.12 & 2612.19 \\
Calcium & 3.58 & 3.56 & 3.55 & 3.51 \\
Total phosphorus & 0.86 & 0.86 & 0.85 & 0.83 \\
Determined analysis (\%) & & & & \\
Crude protein & 16.31 & 15.11 & 15.04 & 14.98 \\
Ether extract & 2.34 & 2.41 & 2.48 & 2.60 \\
Crude fibre & 5.98 & 6.11 & 6.33 & 6.60 \\
ME(kcal/kg) & 2550.00 & 2568.19 & 2571.45 & 2579.10 \\
Calcium & 3.67 & 3.61 & 3.55 & 3.42 \\
Total phosphorus & 0.88 & 0.88 & 0.85 & 0.81 \\
\hline
\end{tabular}

${ }^{1}$ Trace minerals for kg-1 diet contain: $\mathrm{Mn} 40 \mathrm{~g}$; Fe $20 \mathrm{~g}$; Zn $18 \mathrm{~g}$; Cu $0.8 \mathrm{~g}$; Co $0.09 \mathrm{~g}$ and Se $0.04 \mathrm{~g}$. The vitamins for each kg contain: Vit. A 5000000 i.u.; Vit D3 1100000 i.u.; Vit K 0.8 g: Vit B12 8.0 g; Folic acid 0.4 g; Biotin 0.02 g; Vit C 10.0 g; Cholin chloride 120.0 g; Zinc bacitracin 8.0 g; Methionine 80.0 g; Avatec $36.0 \mathrm{~g}$.

${ }^{2}$ Metabolisable energy was calculated using Pauzenga (1985) formula, $[\mathrm{ME}(\mathrm{kcal} / \mathrm{kg})=37(\% \mathrm{CP})+81.8$ $(\% \mathrm{EE})+35.5$ (\% NFE)] 
haemocytometer, respectively (Lamb, 1991). Three birds per treatment were sacrificed and the following organs weighed; liver, kidney, heart and pancreas as described by Udedibie et al. (1996).

\section{STATISTICAL ANALYSIS}

All data were subjected to one - way analysis of variance (ANOVA) for CRD. Differences between the treatment means were separated using Duncan's Multiple Range Test as outlined by Daniel (1991).

\section{RESULTSANDDISCUSSION}

The gross composition of experimental diets is presented in table I. While the proximate composition, gross energy and ricin content of toasted, boiled and boiledand-soaked castor seed meals are presented in table II. Among the treatment methods, only toasting brought about Significant $(\mathrm{p}<0.05)$ differences in crude protein $(\% \mathrm{CP})$ and ricin content of the meal. Other chemical components namely dry matter, crude fiber, ether extract, ash, nitrogen free-extract and gross energy were not affected by processing methods. The crude protein content

Table II. Proximate composition, gross energy and ricin content of processed castor oil seed meal (\% DM basis). (Composición, energía bruta y contenido de ricina de semilla de ricino procesada (\%MS).

\begin{tabular}{lcccc}
\hline & Toasted & Boiled & \multicolumn{3}{c}{$\begin{array}{c}\text { Boiled- } \\
\text { soaked }\end{array}$} \\
& & \multicolumn{3}{c}{ SEM } \\
\hline Dry matter & 87.69 & 84.15 & 82.11 & 7.03 \\
Crude protein & $24.55^{\mathrm{b}}$ & $28.33^{\mathrm{a}}$ & $26.43^{\mathrm{ab}}$ & 2.99 \\
Crude fibre & 21.67 & 19.88 & 18.43 & 2.16 \\
Ether extract & 17.56 & 17.21 & 17.11 & 0.54 \\
Ash & 4.35 & 4.12 & 4.02 & 0.17 \\
NFE & 31.87 & 30.46 & 34.01 & 4.88 \\
Gross energy $^{1}$ & 4.01 & 3.98 & 3.88 & 0.16 \\
Ricin (mg/100 g) & $0.21^{\mathrm{a}}$ & $0.09^{\mathrm{b}}$ & $0.03^{\mathrm{b}}$ & 0.02
\end{tabular}

Means on the same row with different superscripts are significantly different $(p<0.05)$. ${ }^{1} \mathrm{kcal} / \mathrm{g}$. of the toasted meal $(24.55 \%)$ was significantly $(\mathrm{p}<0.05)$ lower than both boiled seed meal $(28.33 \%)$ and boiled-and-soaked seed meal $(26.43 \%)$. The lower level of crude protein in toasted meal could be attributed to the dry heat which quickens the denaturation, complex bond forming with other nutrients especially carbohydrate and subsequent solubilisation of protein due to excessive heat treatment (Nsa, 2008). However, Values obtained from all the treatment methods were higher than the $21.80,22.50$ and 22.39 percent crude protein levels reported for raw kidney bean, lima bean and pigeon pea respectively (Oyenuga, 1968; Okorie et al., 1985; Apata and Ologhobo, 1994; Ukachukwu and Obioha, 1997; Ukotebi, 2002). Nsa and Ukachukwu (2009) have shown that the crude protein value of castor oil seed meal ranks with those of green seed, bambara, groundnut seed, Mucuna cochinenensis, Milletia obanensis, but lower than that of groundnut and soybean seed meal which is the richest in crude protein value among the legume species (Ene-Obong and Carnovale, 1992; Apata and Ologhobo, 1994). This indicates that all the treatment methods retain adequate protein level as a good concentrate source for livestock feeds. The ricin content of the toasted meal $(0.21 \mathrm{mg} / 100 \mathrm{~g})$ was significantly higher than the boiled seed meal $(0.09 \mathrm{mg} / 100 \mathrm{~g})$ and boiled-and-soaked seed meal $(0.03 \%)$. This observation was in consonance with earlier findings by Okorie et al. (1985), where wet treatment was more effective in ricin reduction than dry heat treatment.

The response of laying birds to total replacement of soybean meal with three different methods of processed castor oil seed meals is presented in table III. There was no significant $(\mathrm{p}>0.05)$ difference in the mean daily feed intake (MDFI) of birds across the treatment groups. This indicates that there was no inhibition in the consumption of any of the diets. Any differences observed in other performance parameters could 
therefore only arise from the utilization of the diets.

Significantly better average weight gains (AWG) and average final weight (AFW) were achieved for birds on the control diets, which did not show any significant $(\mathrm{p}<0.05)$ difference with birds on diets containing boiled $\left(\mathrm{T}_{3}\right)$ and boiled-and-soaked castor seed meal $\left(\mathrm{T}_{4}\right)$. Birds on diet containing toasted castor oil seed meal however, had depressed average live weight (ALW) (1.65 $\mathrm{kg}$ ) and AWG (4.22 g). The depressed AWG and FLW of birds on $\mathrm{T}_{2}$ could be due to high residue of ricin. It could be recalled that of all the three treatment methods (table II), the level of ricin was highest in the toasted sample. Ricin has been found by Nsa et al. (2010) to be growth depressant. The mean feed conversion ratio were significantly different $(\mathrm{p}<0.05)$ with birds on treatment diets $\mathrm{T}_{1}, \mathrm{~T}_{3}$ and $\mathrm{T}_{4}$ having similar and better $(p<0.05)$ feed conversion than birds on $T_{2}$. This result shows that birds on $\mathrm{T}_{3}$ were poor converters of feed to dozen of egg, this might be due to the high residue of ricin in the toasted meal. Nsa (2008) reported decrease in egg production as ricin content in laying birds diet increased. The improved performance of the birds on diets containing other test ingredients other than toasted seed meal, suggested enhanced nutritive value which encouraged better utilization by laying birds and could be attributed to the better detoxification of the meal (table II), similar observations were recorded by Udedibie and Mba (1994); Amaefule and Obioha (1998); Finks et al. (1992); Ukachukwu and Anugwa (1995); Nsa et al. (2010) for pigeon pea, pigeon pea, cowpea, soybean and castor oil seed respectively.

The Hen Day Production of birds on the control was significantly better than those on the toasted meal but was similar with birds on the boiled and boiled-and-soaked meals could be due to the poor utilization of the toasted CSM by laying birds. Generally,

Table III. Effect of boiling, boiling-and-soaking and toasting as processing methods of castor oil seed meal in diet on egg production and egg quality of pullets. (Efecto del uso de semilla de ricino (CSM) tostada, hervida, y hervida y humedecida sobre la producción y calidad de los huevos).

\begin{tabular}{lccccc}
\hline & Control diet & Toasted & Boiled & Boiled- soaked & SEM \\
\hline Initial weight (kg/bird) & 1.78 & 1.77 & 1.77 & 1.78 & 0.14 \\
Final weight (kg/bird) & $1.88^{\mathrm{a}}$ & $1.65^{\mathrm{b}}$ & $1.83^{\mathrm{a}}$ & $1.84^{\mathrm{a}}$ & 0.18 \\
Feed intake (g/bird/day) & 142.15 & 133.24 & 139.56 & 140.11 & 7.61 \\
Feed conversion (kg/doz.egg) & $2.31^{\mathrm{b}}$ & $2.89^{\mathrm{a}}$ & $2.45^{\mathrm{b}}$ & $2.38^{\mathrm{b}}$ & 0.17 \\
Hen day production \% & $69.02^{\mathrm{a}}$ & $51.50^{\mathrm{b}}$ & $63.89^{\mathrm{a}}$ & $64.43^{\mathrm{a}}$ & 2.11 \\
Mortality & 0.5 & 1.0 & 0.5 & 1.0 & 0.02 \\
& & & & & \\
Egg weight (g) & 58.14 & 54.12 & 56.97 & 57.13 & 6.11 \\
Albumin height (mm) & 7.98 & 7.79 & 7.81 & 7.65 & 0.78 \\
Albumin weight (g) & 35.60 & 34.78 & 34.86 & 35.13 & 1.88 \\
Haugh unit (H.U.) & 89.22 & 88.34 & 89.06 & 89.14 & 11.44 \\
Shell thickness (mm) & 0.34 & 0.34 & 0.34 & 0.33 & 0.01 \\
Shell weight (g) & 6.92 & 6.86 & 6.88 & 6.84 & 0.77 \\
Yolk/albumin ratio & 0.43 & 0.41 & 0.42 & 0.42 & 0.01 \\
Yolk weight (g) & 15.28 & 15.12 & 15.14 & 15.19 & 3.21 \\
Yolk colour & $9.72^{\mathrm{a}}$ & $4.12^{\mathrm{b}}$ & $5.47^{\mathrm{b}}$ & $5.33^{\mathrm{b}}$ & 0.99 \\
\hline
\end{tabular}

Means on the same row with different superscript differ significantly $(p<0.05)$. 
the values obtained for yolk weight, shell thickness in all the treatment diets including the control were similar to the observation of Odunsi etal. (2002); Ezieshie et al. (2001); Adeniji and Balogun (2002); Olayeni et al. (2007). This was expected since all the birds were mature and of the same age. This agreed with the findings by Abdullah et al. (2003) who reported that the age of the hen strongly influenced the egg size and the proportion of its components. Although, Egg thickness is a good indicator of shell strength and is important in the handling and marketing of eggs to minimize breakage. It therefore appears that the processed Castor oil seed meal were not lacking in nutrients ( minerals and vitamins) directly involved in the formation of a strong shell, and these are mainly calcium, phosphorus, magnesium, chlorine, potassium and vitamins (Waldroup and Hazen, 1978).

The results obtained from the external qualities of eggs and some internal qualities such as egg weight, albumin weight, yolk albumen ratio and yolk weight were expected since all the birds were mature and of the same age. The yolk colour however, was affected significantly ( $\mathrm{p}<0.05)$ by the CSM. Apart from the Control Diet, all other diets with castor oil seed meal encouraged lighter egg yolk colour. This observation was contrary to the reports of Okorie et al. (1985) who reported the raw castor oil seed to be high in carotene $(7-15 \mathrm{mg} / \mathrm{kg})$ a range that is higher than values obtained for other oil seeds. So one should have expected the yolk colour to even be higher with diets with Castor oil seed meal, since pigmented ingredients, especially xanthophylls, cause dark orange yolk and lesser pigmented feed gives a relatively light yellow yolk. However, toasting, cooking and soaking of the seeds might have affected the carotene level of the castor oil seed meal. The haugh unit showed no significant changes $(\mathrm{p}>0.05)$ but however seems to be a bit lower for birds on diet with toasted castor oil seed meal (88.34). Haugh unit is one of the most important parameters for determining the quality of an egg. According to the United States Department of Agriculture (USDA), a haugh unit score of 72 and above (Score AA) is acceptable and connotes freshness in egg (Card and Nesheim, 1972). It could be deduced from

Table IV. Effect of toasting, boiling and boiling-and-soaking as processing methods of castor oil seed meal on carcass characteristics and haematological indices of pullets. (Efecto del uso de semilla de ricino (CSM) tostada, hervida, y hervida y humedecida sobre las características de la canal e índices hematológicos de las aves).

\begin{tabular}{lccccc}
\hline & Control diet & Toasted & Boiled & Boiled- soaked & SEM \\
\hline Dressed weight(kg) & 1.12 & 0.84 & 1.05 & 1.07 & 0.02 \\
Dressing percentage & 59.76 & 51.09 & 57.59 & 58.23 & 1.06 \\
Kidney (\%) & 0.71 & 0.65 & 0.71 & 0.68 & 0.01 \\
Spleen (\%) & 0.11 & 0.15 & 0.13 & 0.13 & 0.01 \\
Liver (\%) & $2.87^{\mathrm{a}}$ & $2.11^{\mathrm{b}}$ & $2.65^{\mathrm{ab}}$ & $2.77^{\mathrm{ab}}$ & 0.19 \\
Pancreas (\%) & 0.39 & 0.51 & 0.44 & 0.40 & 0.08 \\
Heart (\%) & 0.73 & 0.65 & 0.61 & 0.67 & 0.14 \\
Lungs (\%) & 0.71 & 0.73 & 0.68 & 0.66 & 0.03 \\
Hb(g/dl) & $10.67^{\mathrm{a}}$ & $2.23^{\mathrm{b}}$ & $10.11^{\mathrm{a}}$ & $10.35^{\mathrm{a}}$ & 1.01 \\
RBC(x103) & $288.02^{\mathrm{a}}$ & $154.33^{\mathrm{b}}$ & $245.11^{\mathrm{ab}}$ & $251.54^{\mathrm{ab}}$ & 5.43 \\
PCV (\%) & 39.12 & 35.77 & 36.08 & 31.31 & 2.77 \\
\hline
\end{tabular}

Means on the same row with different superscript differ significantly $(p<0.05)$. 
the results that laying birds could tolerate complete replacement of soybean meal with processed castor oil seed meal without sacrificing freshness of egg.

Among the internal organs (table IV) only the liver was significantly $(\mathrm{p}<0.05)$ affected by diet with toasted castor oil seed meal. Birds fed diet containing toasted CSM had a depressed liver weight when compared with birds on other diets. This confirms the claim that liver may be the primary target organ of anti-nutritional factor(s). It could be recalled that of all the three thermal treatments (table II), the ricin level was highest in the toasted sample.

Layers (table IV) on the toasted castor seed meal recorded significantly $(\mathrm{p}<0.05)$ lower haemoglobin $(\mathrm{Hb})$ and red blood cells (RBC). The control diet produced birds with higher Hb, RBC and PCV levels though not significantly different than birds on the

\section{REFERENCES}

Abdullah, A.R., Ojedapo, L.O., Adedeji, T.A., Olayeni, T.B. and Adedeji, S.O. 2003. Influence of hens age on egg quality parameters in Bovans Nera Layer strain. Proc $28^{\text {th }}$ Annual Conference of Nigerian Society of Animal Production. pp. 103-106.

Adeniji, A.A. and Balogun, O.O. 2002. Utilization of flavor treated blood rumen content mixture in the diet of laying hens. Nig J Anim Prod, 29: 34-39.

Amaefule, K.U. and Abioha, F.C. 1998. The substitution of pigeon pea seed (Cajanus cajan) for groundnut cake and maize in broiler finisher ration. Nig J Anim Prod, 25: 9-12.

Ani, A.O. and Okorie, A.U. 2006. The efficacy of two-stage cooking as a method of detoxifying castor oil bean (Ricinus communis $\mathrm{L}$ ) meal for livestock feeding. J Sustain Agric Environ, 8: 14-22.

AOAC. 1995. Association of Official Analytical Chemist. Official Methods of analysis. Washington D.C.

Apata, D.F. and Ologhobo, A.D. 1994. Biochemical evaluation of some Nigerian legume seeds. Food Chem, 49: 33-38.

Bawa, G.S., Abu, E.A. and Adegbulu, M.T. 2007. boiled and boiled-and-soaked CSM. The lower level of RBC and $\mathrm{Hb}$ on toasted CSM was expected because of the relative high level of ricin (table II) which is a form of hemagglutinin.

\section{CONCLUSION}

CSM either boiled for 40 minutes or boiled for 30 minutes followed by soaking for 48 hours can totally replace soybean meal in diets for laying hens without any detrimental effect on egg production, external and internal egg qualities. However, soaking after boiling did not add any advantage to boiling alone in any of the above parameters. In order to improve yolk coloration diet with CSM should be supplemented with pigmented materials. Complete replacement of soybean meal with 40 minutes boiled CSM in laying bird's diet as a feed ingredient would results in substantial cost savings.

Effects of duration of cooking whole or cruched African Locust Bean (Parkia filicoidea, Welw) seeds on the levels of some anti-nutrtional factors and growth performance of young rabbits. Nig J Anim Prod, 34: 208-219.

Borchers, R., Mange, L.D., Nelson, S.O. and Stetson, L.E. 1972. Rapid improvement of raw soybeans by dielectric heating. J Food Sci, 37: 333.

Card, L.E. and Nesheim, M.C. 1972. Poultry production. Lea and Febiger. New York. Philadelphia.

Clarke, R.C.C. and Clarke, M. 1975. Veterinary Toxicology. $1^{\text {st }}$ ed. Bailliers. Tindall. London.

Clemens, E. and Vern, E.A. 1965. Toxity and tolerance of Ricinus communis oil meal for different Animals. Nutr Abstr Rev, 34: 3481.

Daniel, W.W. 1991. Pigmented feedstuffs in poultry nutrition. $5^{\text {th }}$ ed. (1). Biostatistics. A function for analysis in the health science. J. Wisky and Sons. New York.

D'Mello, J.P.F., Acamovic, T. and Walker, A.G. 1985. Nutritive value of jackbean (Canevalia ensiformis) for young chicks. Trop Agric, 62: 145-150. 
Ene-Obong, H.N. and Carnovale, E. 1992. Nigerian Soup condiments: Traditional processing and potential as dietary fibre source. Food Chem, 43: 29-34.

Ezieshie, E.U., Omoregie, A. and Olomu, J.M. 2001. Performance and some physical and internal qualities of eggs of laying chicks fed palm kernel cake based diets. Proc $26^{\text {th }}$ Ann Conf Anim Prod. pp. 199-201.

FAO. 1997. Tropical animal feeding. A manual for research workers. FAO. Rome. pp. 5-10.

Finks, A.J., Jones, D.E. and Jones, C.C. 1992. The role of cystine in the dietary properties of the proteins of the cowpea, Vigna sinensis, and of the proteins pea, Pisum sativum. Biol Chem, 52: 403-410.

Gustafson, M.A., Flegal, C.F. and Schaible, P.J. 1971. The effect of microwave heating on the properties of raw unextracted soybeans for utilization by the chick. Poultry Sci, 50: 358-364.

Harnold, L.M. 2002. Castor bean: An oil crop for mechanical production. Agronomy, 10: 258266.

Haugh, R.R. 1937. The Haugh unit for measuring egg quality. US. Egg Poult Mag, 43: 552-555.

IFSP. 1988. Integrated farming systems programme. Soybean recipes. Institute of Agricultural Research and Training. Moore Plantation. Ibadan. pp. 10-23.

Lamb, G.N. 1991. Manual of veterinary laboratory technique. CIBA_GEIGY. Kenya. pp. 92-109.

Mise, T., Funatsen, I.M. and Isihnie, F.M. 1971. Isolation and separation of ricin from castor bean. Agric Chem, 41: 2041-2042.

NRC. 1994. National Research Council. Nutrient requirements of poultry. National Academy of Sciences. Washington, D.C.

Nsa, E.E. 2008. Chemical and biological assay of castor oil meal (Ricinus communis) as an alternative source in pullet birds diets. PhD Thesis. University of Agriculture. Umudike. Nigeria.

Nsa, E.E. and Ukachukwu, S.N. 2009. Effect of thermal processing methods on the proximate composition, gross energy, minerals and ricin content of undecorticated castor oil meal (Ricinus communis). Global J Agric Sci, 8: 223-228.

Nsa, E.E., Ukachukwu, S.N. and Akpan, I.A. 2010. Growth performance, internal organ development and hematological responses of broiler birds fed diets containing different thermal treated castor oil seed meal (Ricinus communis). Glob J Agric Sci, 9: 39-44.

Odunsi, A.A., Ogunleke, M.O., Alagbe, O.S. and Ajani, T.O. 2002. Effect of feeding Gliricidia sepium leaf meal on the performance and egg quality of layers. Int $J$ Poultry Sci, 1: 26-28.

Olayeni, T.B., Farinu, G.O. and Oyebiyi, O.O. 2007. Replacement value of biscuit waste on the performance and egg quality parameters of laying hens. Proceedings of the $32^{\text {nd }}$ Annual Conference of the Nigerian Society for Animal Production (NSAP). March 18-21. University of Calabar.

Okomato, S., Koga, O., Goto, I., Aramaki, T., Funatsu, M., Takayashi, T. and Murase, K. 1965. Studies on the utilization of castor pomace for animal feed. Japan Poultry Sci, 2: 1-10.

Okorie, A.U., Anugwa, F.O.I., Anamechi, G.C. and Nwaiwu, I. 1985. Heat treated castor oil bean (Ricinus communis). A potential livestock protein supplement in the Tropics. Nutr Rep Int, 32: 659666.

Oyebiyi, O.O., Farinu, G.O. Togun, V.A., Akinlade, J.A. Ajibola, H.O. and Olaniyonu, B.I. 2007. Studies on growth and haematological attributes of weaner rabbits fed graded levels of sundried cassava peel-blood meal mixture. Proceedings of the $32^{\text {nd }}$ Conf. Nigerian Society for Animal Production (NSAP). March, 18-21. University of Calabar. pp. 234-236.

Oyenuga, V.A. 1968. Nigeria's foods and feedstuffs. Their chemistry and nutritive value. Ibadan University press. University of Ibadan.

Pauzenga, V. 1985. Feeding parent stock. Zootech Int, 30: 22-25.

Poliankoff, J. 1980. Production of detoxified castor seed cake. Its use in livestock feeds. Oleaginewix, 15: 793-795.

Raghavan, G.S., Vijaya, J., Harper, M. and Kienholz, E.W. 1974. Nutritive value of salt bed roasted soybeans for broiler chicks. Poultry Sci, 53: 547-553.

Rehman, P.F. 1999. Handbook of crop production in the Tropics. $4^{\text {th }}$ ed. Washington, D.C.

Udedibie, A.B.I. and Mba, U.N. 1994. Studies on the use of pigeon pea (Cajanus cajan) as feed ingredient in layer's diets. J Appl Chem Agric Res, 1: 1-5.

Udedibie, A.B.I., Esonu, B.O., Unachukwu, C. and

Archivos de zootecnia vol. 62, núm. 240, p. 488. 


\section{PERFORMANCE OF LAYERS FED CASTOR OIL SEED MEAL (R. COMMUNIS)}

Iwuoha, N.C. 1996. Two stage cooking as a method of improving the nutritive value of jackbean (Canavalia ensiformis) for broilers. Nig J Anim Prod, 23: 107-110.

Ukachukwu, S.N. and Anugwa, F.O. 1995. Bioeconomics of feeding raw or heat-treated soybeans to broiler chicks. Nig J Anim Prod, 22: 137-140.

Ukachukwu, S.N. and Obioha, F.O. 1997. Chemical evaluation of Mucuna cochinchinensis as alternative protein feedstuff. $J$ Appl Chem Agric Res, 4: 45-54.
Ukotebi, B.A. 2002. Chemical evaluation of the seeds of Millentia obanensis. MSc thesis. University of Calabar. Calabar.

Vietta, E.S. and Thorpe, P.E. 1991. Immunotoxins containing ricin or its A chain. Seminar in Cell Biology, 2: 47-58.

Waldroup, P.W. and Hazen, K.R. 1978. An evaluation of roasted, extruded and raw unextracted soybean in the diet of laying hens. Nutr Rep Int, 18: 99-104.

Weedfact, L. 2003. Sutherland shire counci's Buchcare. J Toxicol Toxin Rev, 14: 483-522. 